\title{
A Preliminary Analysis of Chemical Characteristics of Atmospheric Pollutants and Their Deposition Budget on the Fu-shan Forest in Taiwan
}

\author{
Neng-Huei Lin ${ }^{1}{ }^{*}$, Chung-Te Lee ${ }^{2}$, Chang-Chuan Chan ${ }^{3}$, Wen-Chuang Hsu ${ }^{4}$, Moo-Been Chang ${ }^{2}$, \\ Wen-Lung Lin ${ }^{1}$, Chau-An Hong ${ }^{1}$, Hen-Biau King ${ }^{5}$ and Yue-Joe Hsia ${ }^{6}$
}

(Manuscript received 4 September 1998, in final form 5 January 2000)

\begin{abstract}
This paper presents the chemical characteristics of atmospheric pollutants measured at the Fu-Shan forest (620 m MSL) during two two-weeks field experiments held in the summer and winter of 1993. Chemical compositions of these atmospheric pollutants in solid, gaseous and liquid phases were analyzed. The deposition budget of $S$ and $N$ compounds through dry and wet deposition pathways were particularly assessed. As a result, aerosol mass spectra were found to be bimodal, having the $50 \%$ cut size $<1.0$ $\mu \mathrm{m}$ and around $3.2 \mu \mathrm{m}$ for fine and coarse modes, respectively. In summer, fine and coarse modes were primarily composed of ammonium sulfate and nitrate, respectively. But, in winter the coarse mode was dominated by sea salts due to the influence of northeast monsoon flows. Our average $\mathrm{HNO}_{2}$ $(\sim 0.10$ ppb) was appreciably higher than those observed in clean troposphere, whereas $\mathrm{HNO}_{3}$ was at a comparable level. Meanwhile, ammonia gas and particulate ammonium were at a lower concentration level compared with those generally observed on the continental grounds. The $\mathrm{SO}_{2}$ ( $<1$ ppb) was comparable with those frequently observed in the free troposphere, while $\mathrm{SO}_{4}{ }^{2-}$ was close to the lowest level typically obtained in urban areas. In addition, $\mathrm{NO}_{3}^{-}$which is thought to be associated with local pollution was limited. Therefore, we believe that excessive $\mathrm{SO}_{4}{ }^{2-}$, to a larger extent, was transported to the site via long-range transport, particularly in winter. With regard to the deposition budget, wet deposition pathway ( $>$
\end{abstract}

${ }^{1}$ Department of Atmospheric Sciences, National Central University, Chung-Li, Taiwan, ROC

${ }^{2}$ Graduate Institute of Environmental Engineering, National Central University, Chung-Li, Taiwan, ROC

${ }^{3}$ Institute of Occupational Medicine and Industrial Hygiene, National Taiwan University, Taipei, Taiwan, ROC

${ }^{4}$ Department of Resources Engineering, Dahan Institute of Technology, Hua-Lien, Taiwan, ROC

${ }^{5}$ Division of Forestry Management, Taiwan Forestry Research Institute, Taipei, Taiwan, ROC

${ }^{6}$ Institute of Natural Resource Management, National Dong-Hwa University, Hua-Lien, Taiwan, ROC

${ }^{\star}$ Corresponding author address. Prof. Neng-Huei Lin, Department of Atmospheric Sciences, National

Central University, Chung-Li, Taiwan, ROC; E-mail: nhlin @ rainbow.atm.ncu.edu.tw 


\begin{abstract}
$90 \%$ ) was the most effective mechanism for delivering atmospheric $\mathrm{S}$ and $\mathrm{N}$ compounds to the $\mathrm{Fu}$-Shan forest during the periods of our field experiments.
\end{abstract}

\title{
(Key words: Dry deposition, Wet deposition, Sulfate, Nitrate, Aerosol particle)
}

\section{INTRODUCTION}

The importance of atmospheric inputs onto an ecosystem depends on their net fluxes and duration of existence. They can become either harmful pollutants or vigorous nutrients. For instance, most unpolluted terrestrial environments are $\mathrm{N}$-limited (Vitousek and Matson, 1988). In nature, primary productivity is partially controlled by the amount of $N$ which is made through soil microbial processes, mineralization and immobilization. The input of anthropogenic $\mathrm{N}$ through various atmospheric processes has the potential to alter the natural balance of many ecosystems. Although a small increase in $\mathrm{N}$ deposition can produce a moderate increase in productivity, excessive $\mathrm{N}$ loading may have several adverse effects on both ecosystem health and water quality (Ollinger et al., 1993). In a forest ecosystem, high $\mathrm{N}$ deposition can increase foliar $\mathrm{N}$ concentrations and decrease foliar $\mathrm{Mg}$ and $\mathrm{Ca}$ concentrations, possibly resulting in foliar imbalances or a loss of forest hardness (McNulty et al., 1991). Therefore, assessing the total atmospheric $\mathbf{N}$ deposition is particularly important for understanding the dynamics of nutrient cycling and of the entire $\mathrm{N}$ budget for a forest ecosystem.

Based on measurement data collected during July 12-23, 1993 (hereafter, this period is denoted as "P1"), and December 24, 1993-January 5, 1994 (hereafter, this period is denoted as "P2") at the Fu-Shan Forest, this paper focuses on investigating the exposure of the Fu-Shan forest to atmospheric pollutants, as well as on estimating deposition fluxes of above pollutants on this forest and, subsequently, determining relative contribution of various deposition pathways to total deposition budget.

The Fu-Shan site $\left(24^{\circ} 46^{\prime} \mathrm{N}\right.$ and $\left.121^{\circ} 43^{\prime} \mathrm{E}\right)$ is located in the Fu-Shan Research Station of the Taiwan Forest Research Institute (TFRI) in northem Taiwan, as illustrated in Fig. 1. The Station is about $25 \mathrm{~km}$ away from the nearest urban area. There are no heavy industries, just agriculture and fisheries in the surrounding region. The site is about $620 \mathrm{~m}$ in elevation and its surrounding area of around 1100 ha has been preserved as a natural conservation zone for animals and forests. In the Fu-Shan forest, about $90 \%$ of the total area exceeds $600 \mathrm{~m}$ in elevation. The highest elevation is $1419 \mathrm{~m}$. Inside the Station, a natural garden for plants, the first one of its kind in Taiwan, has been managed. This area is largely forested by chinkapin, red machilus, yellow basket willow, Chinese meliosma, litsea, narrow leafed oak, gold colored neolitsea and Pyrenaria shinkoensis (King and Hsia, 1997).

The Station is bathed in warm and humid weather conditions in summer, but experiences cool and wet northeast monsoon flows in winter. The temperature at this site ranges between 12 and $27^{\circ} \mathrm{C}$ with a mean value of $19^{\circ} \mathrm{C}$ (King and Hsia, 1997). The annual rainfall is about $3300 \mathrm{~mm}$, and the relative humidity is above $75 \%$ all the year round, having a mean value of $88 \%$. It is noted that mountain-valley circulations were frequently observed during the experi- 


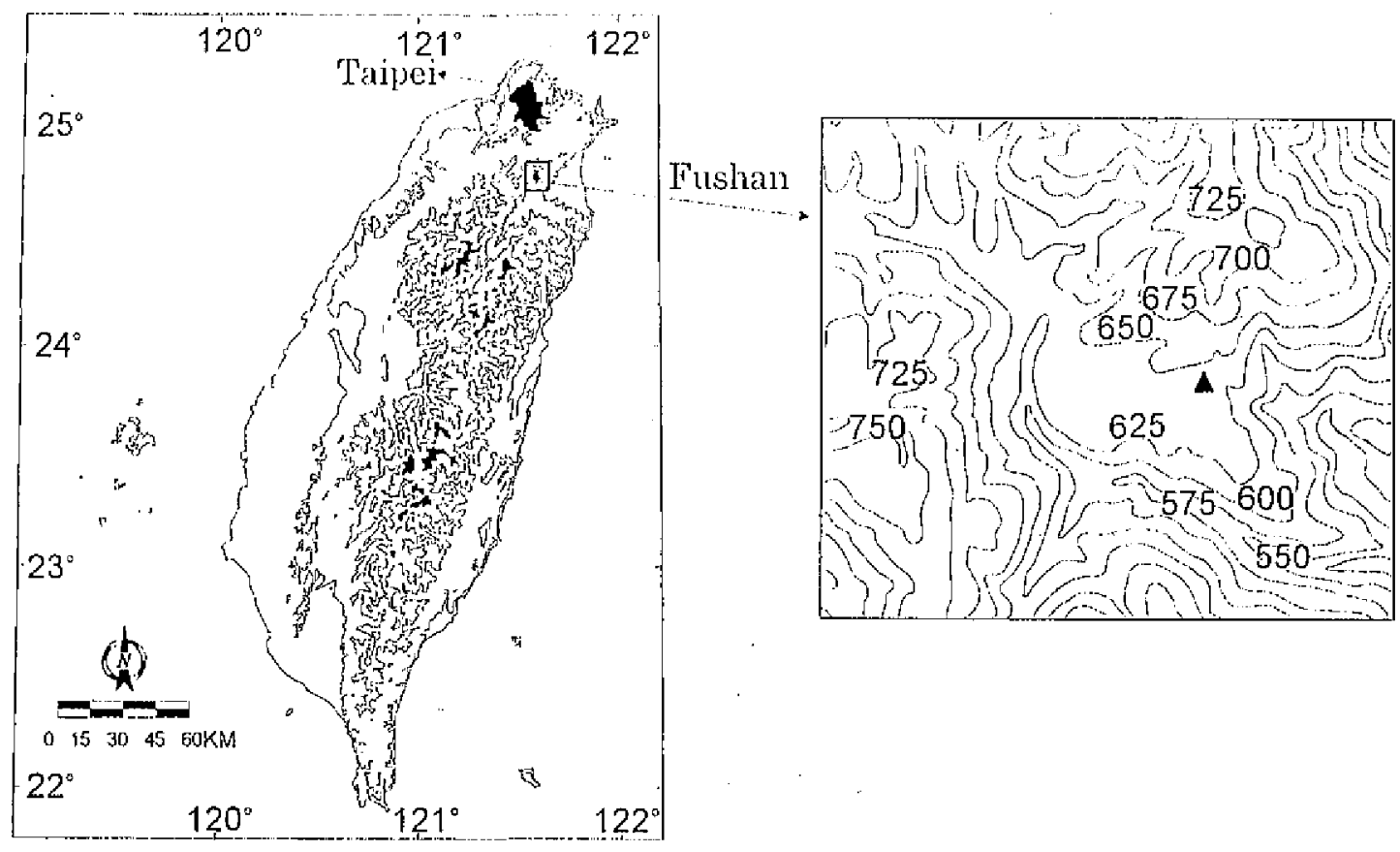

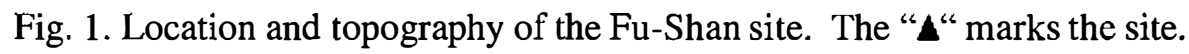

mental periods. Easterly winds prevail during the daytime period, generally traveling through the valley along an east-west direction. In summer, the weather is primarily dominated by the Pacific high. Warm and humid airmasses typically intrude into the region along the outflow of the high pressure system. Afternoon thunderstorms in the mountain areas frequently occur due to local convections. In winter, cool and wet northeast monsoon flows prevail in region, generally enriched by marine aerosols and sulfates (Lin et al., 1999).

Table 1. lists the parameters measured and instruments utilized in this work. Aerosol particles (AP) were collected using the Micro-Orifice Uniform Deposit Impactor (MOUDI, see Marple et al., 1991). The pressure drop of MOUDI was routinely checked and manually maintained at a certain level based on their calibration curves. The MOUDI consists of eight stages for collecting particles with aerodynamic diameters of $50 \%$ cut points ranging from 0.185 to $10 \mu \mathrm{m}$ (as shown in Fig. 2). The first stage after inlet and last stage after filter collect AP between 10 and $18 \mathrm{~mm}$ and $\mathrm{AP}<0.185 \mu \mathrm{m}$, respectively. In consideration of relatively clean air in the mountain environments, the samples were taken on a 48-hour basis during summer measurements, compared with 24-hour or less sampling time which is often adopted in urban areas. In winter, the sampling duration was shortened to 24 hours since the summer measurements suggested an affordability of analytical techniques.

Gaseous pollutants including nitrous acid $\left(\mathrm{HNO}_{2}\right)$, nitric acid $\left(\mathrm{HNO}_{3}\right)$, sulfur dioxide $\left(\mathrm{SO}_{2}\right)$ and ammonia $\left(\mathrm{NH}_{3}\right)$ were collected using the annular denuder of four tubes (Perrino et al., 1990). A flow rate of $10 \ell \mathrm{min}^{-1}$ was adopted. The samples were mostly taken on a 24-hour basis except for the first run of 48-hour sampling on July 13, 1993. 
Table 1. Parameters measured and instruments used at the Fu-Shan site during P1 (summer) and P2 (winter).

\begin{tabular}{|c|c|}
\hline Parameter & Instrument \\
\hline \multicolumn{2}{|l|}{ Meteorological measurements } \\
\hline $\begin{array}{l}\text { Wind speed } \\
\text { Wind direction } \\
\text { Air temperature } \\
\text { Barometric pressure } \\
\text { Relative humidity } \\
\text { Solar radiation } \\
\text { Precipitation }\end{array}$ & Handar-555 portable meteorological tower \\
\hline Sample collection & \\
\hline Liquid phase & - \\
\hline Rain water & Acid Precipitation Sampler Model-APS \\
\hline Solid phase & \\
\hline Particle mass spectrum & MSP MOUDI \\
\hline Gaseous phase & \\
\hline $\mathrm{NH}_{3}, \mathrm{HNO}_{2}, \mathrm{HNO}_{3}$ and $\mathrm{SO}_{2}$ & Annular denuder \\
\hline Chemical analysis & \\
\hline $\begin{array}{l}\mathrm{pH} \\
\text { Anion } \\
\text { Cation }\end{array}$ & $\begin{array}{l}\text { Electrode probe } \\
\text { Ion Chromatography } \\
\text { Ion Chromatography and } \\
\text { Atomic Absorption Spectrometry }\end{array}$ \\
\hline
\end{tabular}

Rainwater was collected on a daily basis utilizing the wet/dry collector (Acid Precipitation Sampler-Model APS) which is identical to the one deployed by the USA National Atmospheric Deposition Program/National Trends Network (NADP/NTN). The TFRI was responsible for rainwater collection. The rainfall amount was recorded using a conventional tipping bucket gauge.

The above collected samples in three phases were chemically analyzed. Rainwater samples were analyzed for concentrations of $\mathrm{Cl}^{-}, \mathrm{NO}_{3}{ }^{+}, \mathrm{SO}_{4}{ }^{2-}, \mathrm{NH}_{4}^{+}, \mathrm{Na}^{+}, \mathrm{K}^{+}, \mathrm{Ca}^{2+}$ and $\mathrm{Mg}^{2+}$. The $\mathrm{H}^{+}$ concentration was converted from the $\mathrm{pH}$ of rainwater. The samples collected by annular denuder were analyzed to determine the concentration levels of gases $\mathrm{NH}_{3}, \mathrm{HNO}_{2}, \mathrm{HNO}_{3}$, and $\mathrm{SO}_{2}$. Ion compositions of water soluble aerosol particles collected by MOUDI were analyzed 
Summer
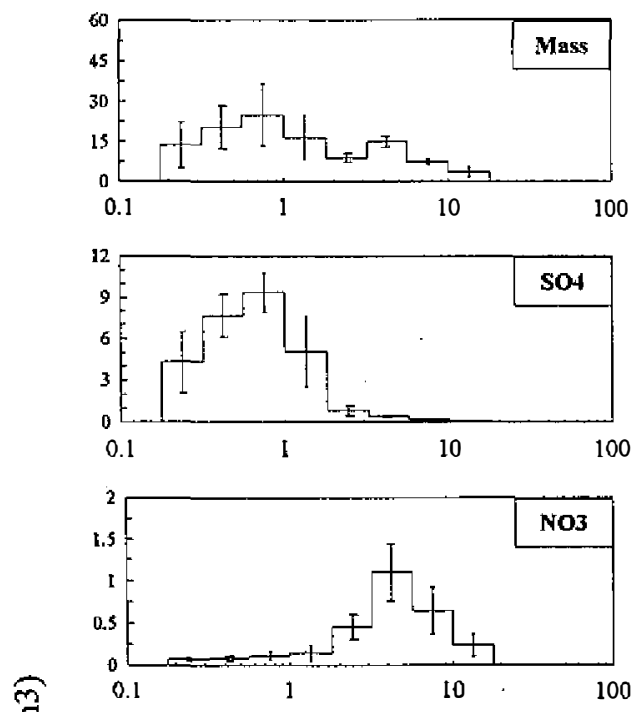

5
$\vdots$
0
0
0
0
0
0
0
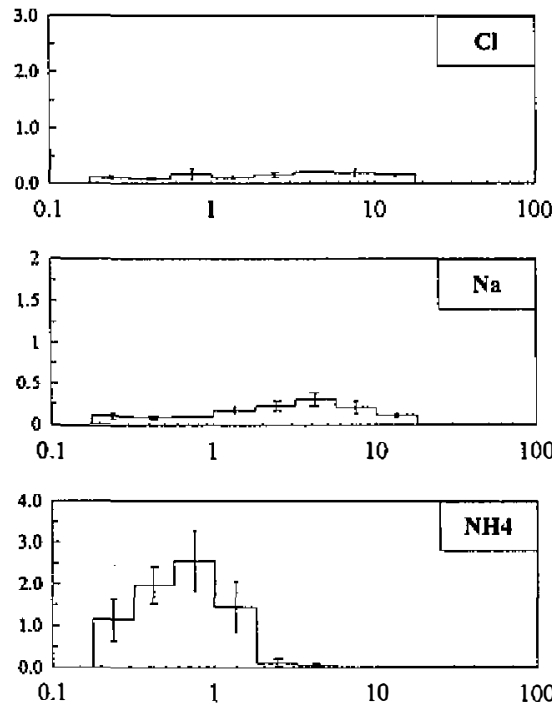

100

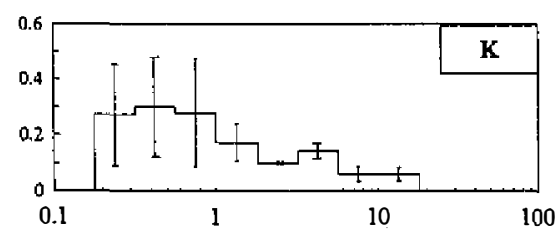

Cut Size $(\mu \mathrm{m})$
Winter
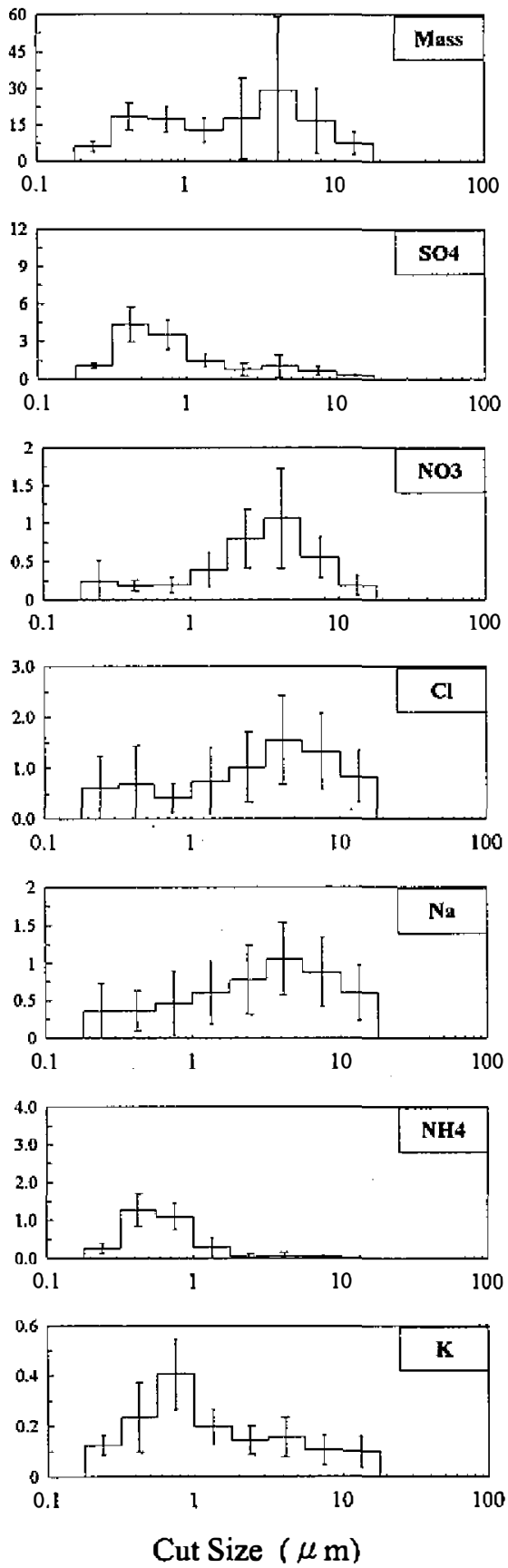

Fig. 2. Average mass spectrum of aerosol particles and corresponding water soluble compositions collected at the Fu-Shan site during P1 (summer) and $\mathrm{P} 2$ (winter). 
for $\mathrm{Cl}^{-}, \mathrm{NO}_{2}^{-}, \mathrm{NO}_{3}^{-}, \mathrm{SO}_{4}^{2-}, \mathrm{NH}_{4}^{+}, \mathrm{Na}^{+}$and $\mathrm{K}^{+}$. Detailed analytical procedures are not given here since they are generally common.

\section{AEROSOL PARTICLES}

The aerosol particles (AP) with a cut size $\leq 10 \mu \mathrm{m}$ are categorized as $\mathrm{PM}_{10}$. They are further divided into FP (Fine particle) and $\mathrm{CP}$ (Coarse particle) with the cutting diameter at 2.5 $\mu \mathrm{m}$ as conventionally used. However, the MOUDI does not have a clear cutting point at 2.5 $\mu \mathrm{m}$. Hence, aerosols with cutting diameters less than and greater than $2.5 \mu \mathrm{m}$ are attributed to FP and CP, respectively. Detailed discussion is given below.

\subsection{Aerosol Mass Spectra}

Figure 2 depicts the average mass spectra of AP and their water-soluble ions, as annotated in the legends, over the entire sampling periods P1 and P2. Evidently, the bimodality in AP mass concentration can be found. The modes of FP and CP were at the diameters $<1.0 \mu \mathrm{m}$ ( 0.56 and $0.32 \mu \mathrm{m}$ during $\mathrm{P} 1$ and $\mathrm{P} 2$, respectively) and $3.2 \mu \mathrm{m}$, respectively. During P1, average mass concentration of the fine mode $\left(6.27 \mu \mathrm{g} \mathrm{m}^{-3}\right)$ was $74 \%$ higher than that of the coarse mode $\left(3.60 \mu \mathrm{g} \mathrm{m}^{-3}\right)$. The fine mode mostly consisted of ammonium sulfate (see Fig. 2), indicating a possible influence of local production of ammonia. By contrast, the coarse mode was largely composed of nitrate salts. However, the average mass concentration of watersoluble ions for the fine mode $\left(3.16 \mu \mathrm{g} \mathrm{m}^{-3}\right)$ was approximately six times that for coarse mode $\left(0.56 \mu \mathrm{g} \mathrm{m}^{-3}\right)$. These undetermined compositions of coarse particles may be attributed to crustal materials from natural processes (Seinfeld, 1986). But, the fine particles of high solubility to water were mainly the secondary products (e.g., $\mathrm{SO}_{4}{ }^{2-}$ ). Unlike the results of summer measurements during $\mathrm{P} 1$, average mass concentration of the fine mode $\left(4.46 \mu \mathrm{g} \mathrm{m}^{-3}\right)$ was about $63 \%$ of that of coarse mode $\left(7.07 \mu \mathrm{g} \mathrm{m}^{-3}\right)$ for winter measurements during P2. This contrast can be attributed to the abundance of sea salts in the coarse mode, as illustrated in Fig. 2. Obviously, wintertime northeast monsoon flow brought higher marine aerosols to our site. Still, ammonium sulfate in fine mode during Pl was more than twice that during P2, indicating a relatively lower formation rate of fine particles in winter due to colder temperatures.

\section{2 $\mathrm{PM}_{10}$}

Table 2 lists average mass concentrations of chemical compositions for FP, CP and $\mathrm{PM}_{10}$ during P1 and P2. During P1, $\mathrm{PM}_{10}$ ranged from 16.2 to $43.1 \mu \mathrm{g} \mathrm{m}^{-3}$ (which is not shown in Table) with an average of $29.1 \mathrm{\mu g} \mathrm{m}^{-3}$. As to the chemical composition of aerosol particles, the water soluble ions including $\mathrm{Cl}^{-}, \mathrm{NO}_{2}^{-}, \mathrm{NO}_{3}^{-}, \mathrm{SO}_{4}{ }^{2-}, \mathrm{NH}_{4}^{+}, \mathrm{Na}^{+}$, and $\mathrm{K}^{+}$, weighed 11.2 $22.3 \mu \mathrm{g}$ $\mathrm{m}^{-3}$ (mean \pm standard deviation), accounting for $40.2 \pm 6.1 \%$ of $\mathrm{PM}_{10}$ mass. Meanwhile, $\mathrm{SO}_{4}^{2-}$ alone can account for $66.1 \pm 0.8 \%$ of total ions. The secondary ion was $\mathrm{NH}_{4}^{+}(17.2 \pm 0.8 \%)$, followed by $\mathrm{NO}_{3}^{-}(6.6 \pm 0.9 \%)$. The $\mathrm{SO}_{4}{ }^{2-}$ contributed about 10 times the $\mathrm{NO}_{3}^{-}$to $\mathrm{PM}_{10}$ mass. Sea salts, including $\mathrm{Cl}$ and $\mathrm{Na}^{+}$, were only $3.0 \pm 0.6 \%$ and $3.3 \pm 0.5 \%$ of total ions, respectively. Potassium was at about the same level as sea salts. The above results indicated that $\mathrm{SO}_{4}{ }^{2-}$ 
Table 2. Average mass concentrations of FP, CP and $\mathrm{PM}_{10}$, as well as the water-soluble ion compositions and their fractions of total ions, collected by MOUDI at the Fu-Shan site during P1 and P2 (Unit: $\mu \mathrm{g} \mathrm{m}^{-3}$ ).

\begin{tabular}{|c|c|c|c|c|c|c|c|c|c|c|}
\hline Season & & mass & $\mathrm{ION}^{*}$ & $\mathrm{Cl}^{-}$ & $\mathrm{NO}_{2}^{-}$ & $\mathrm{NO}_{3}^{-}$ & $\mathrm{SO}_{4}^{2-}$ & $\mathrm{NH}_{4}^{+}$ & $\mathrm{Na}^{+}$ & $\mathrm{K}^{+}$ \\
\hline \multicolumn{11}{|c|}{ P1 (Summer observations) } \\
\hline \multirow[t]{2}{*}{$\mathrm{FP}$} & $\mu \pm \sigma$ & $22.82 \pm 8.75$ & $10.07 \pm 2.15$ & $0.18 \pm 0.03$ & $0.03 \pm 0.03$ & $0.23 \pm 0.03$ & $7.19 \pm 1.52$ & $1.91 \pm 0.48$ & $0.20 \pm 0.02$ & $0.33 \pm 0.16$ \\
\hline & $\%$ of ION & & & $1.9 \pm 0.4$ & $0.3 \pm 0.3$ & $2.4 \pm 0.6$ & $71.4 \pm 0.6$ & $18.8 \pm 0.8$ & $2.1 \pm 0.4$ & $3.1 \pm 0.9$ \\
\hline \multirow[t]{2}{*}{$\mathrm{CP}$} & & $6.27 \pm 1.03$ & $1.08 \pm 0.20$ & $0.14 \pm 0.02$ & $0.03 \pm 0.03$ & $0.49 \pm 0.15$ & $0.18 \pm 0.03$ & $0.02 \pm 0.01$ & $0.16 \pm 0.03$ & $0.07 \pm 0.01$ \\
\hline & & & & $13.1 \pm 2.1$ & $2.5 \pm 2.7$ & $44.6 \pm 6.4$ & $16.9 \pm 1.5$ & $1.8 \pm 1.5$ & $14.7 \pm 0.8$ & $6.3 \pm 1.9$ \\
\hline \multirow[t]{2}{*}{$\mathrm{PM}_{10}$} & & $29.09 \pm 9.64$ & $11.15 \pm 2.33$ & $0.32 \pm 0.05$ & $0.05 \pm 0.05$ & $0.72 \pm 0.15$ & $7.37 \pm 1.55$ & $1.93 \pm 0.47$ & $0.36 \pm 0.04$ & $0.39 \pm 0.15$ \\
\hline & & & & $3.0 \pm 0.6$ & $0.5 \pm 0.5$ & $6.6 \pm 0.9$ & $66.1 \pm 0.8$ & $17.2 \pm 0.8$ & $3.3 \pm 0.5$ & $3.40 \pm 0.6$ \\
\hline \multicolumn{11}{|c|}{ P2 (Winter observations) } \\
\hline \multirow[t]{2}{*}{ FP } & $\mu \pm \sigma$ & $19.24 \pm 6.06$ & $6.30 \pm 0.61$ & $1.04 \pm 0.67$ & $0.07 \pm 0.07$ & $0.49 \pm 0.12$ & $2.86 \pm 0.63$ & $0.76 \pm 0.23$ & $0.77 \pm 0.47$ & $0.32 \pm 0.07$ \\
\hline & $\%$ of $10 N$ & & & $16.0 \pm 9.8$ & $1.1 \pm 1.0$ & $7.7 \pm 1.6$ & $46.0 \pm 12.0$ & $12.3 \pm 4.1$ & $11.7 \pm 6.5$ & $5.0 \pm 1.0$ \\
\hline \multirow[t]{2}{*}{$\mathrm{CP}$} & & $13.15 \pm 10.89$ & $2.62 \pm 1.06$ & $0.93 \pm 0.44$ & $0.0 \mathrm{I} \pm 0.01$ & $0.44 \pm 0.19$ & $0.49 \pm 0.30$ & $0.03 \pm 0.03$ & $0.63 \pm 0.29$ & $0.09 \pm 0.04$ \\
\hline & & & & $34.8 \pm 10.0$ & $0.4 \pm 0.6$ & $17.8 \pm 7.1$ & $18.3 \pm 7.5$ & $1.4 \pm 1.4$ & $23.7 \pm 4.9$ & $3.6 \pm 1.4$ \\
\hline \multirow[t]{2}{*}{$\mathrm{PM}_{10}$} & & $32.39 \pm 16.15$ & $8.92 \pm 1.42$ & $1.97 \pm 0.89$ & $0.08 \pm 0.08$ & $0.93 \pm 0.28$ & $3.34 \pm 0.83$ & $0.79 \pm 0.24$ & $1.40 \pm 0.63$ & $0.41 \pm 0.09$ \\
\hline & & & & $21.6 \pm 9.1$ & $0.9 \pm 0.9$ & $10.4 \pm 2.5$ & $38.2 \pm 10.3$ & $9.2 \pm 3.6$ & $15.2 \pm 5.9$ & $4.6 \pm 1.0$ \\
\hline
\end{tabular}

* The total mass concentration of water soluble ions. 
played a more dominant role in ion composition of $\mathrm{PM}_{10}$ collected at our site in $\mathrm{P} 1$.

During P2 measurements, $\mathrm{SO}_{4}{ }^{2-}$ was still the principal component $(38.2 \pm 10.3 \%$ of total ions) in $\mathrm{PM}_{10}$, but it was less than half of that observed during $\mathrm{P} 1$. In addition, sea salts $\left(\mathrm{Cl}^{-}\right.$ and $\mathrm{Na}^{+}$), accounting for about $37 \%$ of total ions, became another dominant component. Meanwhile, by mass, they were almost five times that during $\mathrm{P} 1$, indicating a strong influence of marine aerosols associated with monsoon flows. $\mathrm{NO}_{3}^{-}$during $\mathrm{P} 2$ was at about the same level as that during $\mathrm{P} 1$. Photochemical products $\left(\mathrm{NO}_{3}{ }^{-}\right)$were relatively limited at our site, indicative of a lack of local sources of their precursors (e.g., $\mathrm{NO}_{\mathrm{x}}$ ).

In summary, $\mathrm{SO}_{4}{ }^{2-}$ was comparable with other rural sites (Dasch and Cadle, 1985; Lindberg et al., 1986; Muller and Weatherford, 1988; Ohta and Okita, 1990; Sopauskiene and Budvytyte, 1994), and significantly less than the lowest limit of around $10 \mu \mathrm{g} \mathrm{m}^{-3}$, generally measured in urban areas (Tanner, 1990). On the other hand, $\mathrm{NO}_{3}^{-}$was evidently lower than those in other rural areas. These findings suggested that the Fu-Shan site was relatively less influenced by anthropogenic pollutants, such as sulfate and nitrate aerosols.

\subsection{Fine and Coarse Particles}

As seen in Table 2, during P1, the FP and CP were $22.8 \pm 8.8$ and $6.3 \pm 1.0 \mu \mathrm{g} \mathrm{m}^{-3}$, respectively. Meanwhile, they accounted for $78.4 \%$ and $21.6 \%$ of $\mathrm{PM}_{10}$, respectively. On average, $44.1 \%$ and $17.3 \%$ of FP and CP mass, respectively, were determined as water soluble ions. In comparison with FP mass, the above decrease in water soluble ions of CP mass was probably due to undetermined cations such as $\mathrm{Mg}^{2+}$ and $\mathrm{Ca}^{2+}$, since they were generally favored with CP. For FP, $\mathrm{SO}_{4}^{2-}$ alone can account for $71.4 \%$ of total ions, compared with only $16.9 \%$ for CP. Ammonium (18.8\%) was the secondary component of FP. In contrast, $\mathrm{NO}_{3}^{-}$can account for about half of total ions for $\mathrm{CP}$, whereas sea salts and sulfate were at about the same level and both approximately accounted for the other half of total ions. As to the partition of individual ions to $\mathrm{FP}$ and $\mathrm{CP}$, it was equivalent for $\mathrm{Cl}^{-}, \mathrm{Na}^{+}$and $\mathrm{NO}_{2}^{-}$. Nitrate was favored in $\mathrm{CP}$ (68\%), whereas more than $95 \%$ of $\mathrm{SO}_{4}{ }^{2 \cdot}$ fell into $\mathrm{FP}$, as well as $\mathrm{NH}_{4}^{+}$. The above observations are consistent with the general knowledge that gaseous nitric acids tend to deposit on coarse particles to form nitrate particles. By contrast, the sulfates form as fine particles through a gasto-particle conversion mechanism.

During P2, the FP and CP were $19.2 \pm 6.1$ and $13.1 \pm 10.1 \mu \mathrm{g} \mathrm{m}^{-3}$, contributing $59.4 \%$ and $40.6 \%$ of $\mathrm{PM}_{10}$, respectively. On average, $32.7 \%$ and $19.9 \%$ of FP and CP, were water soluble ions, respectively. The $\mathrm{CP}$ during $\mathrm{P} 2$ was more than twice that during $\mathrm{P} 1$, whereas the FP during $\mathrm{P} 2$ was only about $60 \%$ of that during P1. As discussed in the preceding subsection, this result was attributed to the enhancement of $\mathrm{CP}$ by marine aerosols during P2. Table 2 shows that sea salts in $\mathrm{CP}$ during P2 were much higher than those during P1. However, $\mathrm{NO}_{3}$ remained at the same level $\left(0.4-0.5 \mu \mathrm{g} \mathrm{m}^{-3}\right)$ during both periods of field experiments, suggesting that stable photochemical conditions persisted at our site, resulting in no excess of $\mathrm{NO}_{3}{ }^{-}$ formed on the surface of marine aerosols. Regarding the relative contribution of individual ions to total ions, for FP, $\mathrm{SO}_{4}{ }^{2-}$ decreased $25 \%$ from P1 to P2, compared with a slight increase for $\mathrm{CP}$. This result was primarily attributed to a dramatic increase of $\mathrm{Cl}^{-}$and $\mathrm{Na}^{+}$, as well as to a decrease of $\mathrm{SO}_{4}{ }^{2-}$, in FP during P2. Similarly, $\mathrm{NO}_{3}{ }^{-}$in $\mathrm{CP}$ decreased from $44.6 \%$ during P1 
to $17.8 \%$ during $\mathrm{P} 2$. The nitrate during $\mathrm{P} 2$ was no longer dominant in $\mathrm{CP}$, as it was during $\mathrm{P} 1$. The above results indicated that the characteristics of aerosol particles during P2 were significantly altered due to the addition of marine aerosols, strongly depending upon the meteorological conditions.

\section{GASEOUS MEASUREMENTS BY ANNULAR DENUDER SYSTEM}

Table 3 lists average concentration levels of nitrous acid $\left(\mathrm{HNO}_{2}\right)$, nitric acid $\left(\mathrm{HNO}_{3}\right)$, sulfur dioxide $\left(\mathrm{SO}_{2}\right)$ and ammonia $\left(\mathrm{NH}_{3}\right)$ gases measured during $\mathrm{P} 1$ and $\mathrm{P} 2$ using the annular denuder. Our average $\mathrm{HNO}_{2}$ concentration of 0.17 and 0.31 ppb during $\mathrm{P} 1$ and $\mathrm{P} 2$, respectively, were appreciably higher than those in the clean troposphere, which is on the order of $10^{-}$ ${ }^{3} \mathrm{ppb}$ (Harris et al., 1982). $\mathrm{HNO}_{2}$ during $\mathrm{P} 2$ was almost twice that during P1.

Our concentration level of $\mathrm{HNO}_{3}$ during $\mathrm{Pl}, 0.28 \pm 0.02 \mathrm{ppb}$, was comparable with, but slightly higher than, those observed in the clean troposphere (Hanst et al., 1982), which were generally measured at $0.02-0.30 \mathrm{ppb}$. By contrast, during $\mathrm{P} 2$, our $\mathrm{HNO}_{3}$ was on the order of $10^{-2} \mathrm{ppb}$. In the boundary layer troposphere, the oxidation of $\mathrm{NO}_{2}$ by $\mathrm{OH}$ radicals is the major routine of $\mathrm{HNO}_{3}$ formation during daylight hours. A second mechanism, involving $\mathrm{NO}_{3}$ chemistry, for $\mathrm{HNO}_{3}$ formation is also important at night. In the presence of $\mathrm{H}_{2} \mathrm{O}$, the $\mathrm{HNO}_{2}$ and $\mathrm{HNO}_{3}$ can be formed through the heterogeneous reactions of $\mathrm{NO}_{2}$ with aerosol particles and fog droplets (Warneck, 1988). Our $\mathrm{HNO}_{3}$ during $\mathrm{P} 1$ could result from active photochemistry during this favorable season.

Previous observations (Warneck, 1988) indicated that, by and large, $\mathrm{HNO}_{3}$ and aerosol nitrate were present in the atmosphere with comparable concentrations. Most of ground-based measurements showed a moderate excess of particulate nitrate, so that the $\mathrm{HNO}_{3} / \mathrm{NO}_{3}{ }^{-}$mass ratio was generally less than unity. In the free atmosphere, the relation was reversed. It can be no doubt that in the ground-level atmosphere such a ratio is strongly influenced by the losses of $\mathrm{HNO}_{3}$ resulting from its very high dry deposition velocity of $2-3 \mathrm{~cm} \mathrm{~s}^{-1}$ (Huebert and Robert, 1985). Table 3 shows that our $\mathrm{HNO}_{3} / \mathrm{NO}_{3}^{-}$mass ratio during $\mathrm{P} 1$ averages as unity as expected for ground atmosphere. However, our average $\mathrm{NO}_{3}^{-}$of $0.72 \mu \mathrm{g} \mathrm{m}^{-3}$ (Table 2) was comparable with those observed in free atmosphere (Huebert and Lazrus, 1980). During P2, this ratio was much less than unity, indicative of inactive photooxidation chemisty of $\mathrm{NO}_{\mathrm{x}}$ during the experimental period, perhaps, a high deposition rate of $\mathrm{HNO}_{3}$ on the surface as well. Combining gaseous with particulate nirrates as total nitrates, they averaged 1.44 and $1.03 \mu \mathrm{g} \mathrm{m}^{-3}$ during P1 and $\mathrm{P} 2$, respectively.

For another $\mathrm{N}$-originated species, ammonia gas and particulate ammonium during $\mathrm{Pl}$ were $1.40 \pm 0.21 \mathrm{ppb}$, and $1.93 \pm 0.47 \mu \mathrm{g} \mathrm{m}^{-3}$, respectively. A great excess of particulate $\mathrm{NH}_{4}^{+}$ over $\mathrm{NO}_{3}$ obviously had neutralized $\mathrm{SO}_{4}{ }^{2}$, as revealed by the molar ratio of $\mathrm{NH}_{4}{ }^{+} / \mathrm{SO}_{4}{ }^{2}$ (which can be calculated to be 1.40 as converted from the mass ratio). Our result suggested that the ammonium salt of sulfuric acid co-existed with that of nitric acid. During P2, ammonia gas and particulate ammonium were less than $50 \%$ of those during P1, indicating that ammonia production became less in a colder environment.

In addition, our average mass ratio of $\mathrm{NH}_{3} / \mathrm{NH}_{4}{ }^{+}$was found to be significantly less than 
Table 3. Gaseous pollutants measured by the annular denuder at the Fu-Shan site.

\begin{tabular}{|c|c|c|c|c|c|c|c|c|c|}
\hline \multirow[t]{2}{*}{ Season } & & \multicolumn{4}{|c|}{ Gaseous matters (ppb) } & \multicolumn{3}{|c|}{ Concentration ratio $\left(\mu \mathrm{g} \mu \mathrm{g}^{-3}\right)^{\mathrm{a}}$} & \multirow{2}{*}{$\frac{\text { Total nitrate }\left(\mu \mathrm{g} \mathrm{m}^{-3}\right)}{\mathrm{HNO}_{3}+\mathrm{NO}_{3}^{-}}$} \\
\hline & & $\mathrm{HNO}_{2}$ & $\mathrm{HNO}_{3}$ & $\mathrm{SO}_{2}$ & $\mathrm{NH}_{3}$ & $\mathrm{NH}_{4}{ }^{+} / \mathrm{SO}_{4}{ }^{2-}$ & $\mathrm{HNO}_{3} / \mathrm{NO}_{3}^{-}$ & $\mathrm{NH}_{3} / \mathrm{NH}_{4}^{+}$ & \\
\hline \multirow[t]{3}{*}{ Pl (Summer observations) } & $\mu$ & 0.17 & 0.28 & 0.25 & 1.40 & 0.26 & 1.00 & 1.05 & 1.44 \\
\hline & $\sigma$ & 0.04 & 0.02 & 0.03 & 0.21 & & & & \\
\hline & $\mathrm{n}$ & 5 & 5 & 5 & 5 & 5 & 5 & 5 & 5 \\
\hline \multirow[t]{3}{*}{ P2 (Winter observations) } & $\mu$ & 0.31 & 0.04 & 0.63 & 0.37 & 0.24 & 0.11 & 0.68 & 1.03 \\
\hline & $\sigma$ & 0.10 & 0.01 & 0.14 & 0.14 & & & & \\
\hline & $\mathrm{n}$ & 8 & $3^{b}$ & 11 & 10 & 11 & 3 & 10 & 11 \\
\hline
\end{tabular}

a. Mean concentrations of aerosol particles $\left(\mathrm{PM}_{10}\right)$ were adopted from Table 2.

b. Only 3 samples were above the detection limit. 
unity during P2, indicating a preference of atmospheric ammonia in particulate phase. Our value was comparable with those found elsewhere (for example, Georgii and Lenhard, 1978). The $\mathrm{NH}_{3} / \mathrm{NH}_{4}^{+}$ratio should be determined by the rate at which ammonia is tied to aerosol particles following the production of sulfuric acid and nitric acid, relative to the rates of ammonia supply and its removal from the atmosphere by precipitation. By inspecting the ratio of $\mathrm{NH}_{3} \mathrm{NH}_{4}^{+}$, it was found that particulate ammonium existed preferably during the winter season, because of a lower temperature.

With regard to sulfur compounds, the continental background of $\mathrm{SO}_{2}$ in regions not directly influenced by anthropogenic emissions has remained largely unexplored (Warneck, 1988). Our $\mathrm{SO}_{2}$ varied within $0.25 \pm 0.03$ and $0.63 \pm 0.14 \mathrm{ppb}$ during $\mathrm{P} 1$ and $\mathrm{P} 2$, which were about one order in magnitude lower than those generally found in nonurban areas (for example, Altshuller, 1976, 1980), but were comparable with those observed (for example, Ryaboshapko, 1983) in the free troposphere (outside the boundary layer). By contrast, $\mathrm{SO}_{2}$ in polluted air was frequently observed to be greater than $10 \mathrm{ppb}$. As to secondary pollutants, $\mathrm{SO}_{4}^{2-}$ particles measured at our site averaged $7.37 \pm 1.55 \mu \mathrm{g} \mathrm{m}^{-3}$ during P1, which was close to the lowest level of around $10 \mathrm{\mu g} \mathrm{m}^{-3}$, in general, obtained in urban areas (Tanner, 1980). However, during P2, our $\mathrm{SO}_{4}{ }^{2-}$ of $3.34 \pm 0.83 \mu \mathrm{g} \mathrm{m}^{-3}$ showed a smaller range of fluctuation, indicating that relatively clean air masses arrived at the site. According to Muller and Weatherford (1988), average

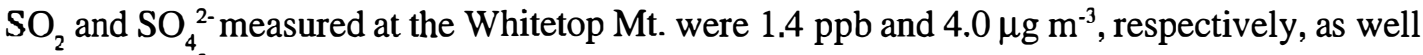
as $1.5 \mu \mathrm{g} \mathrm{m}^{-3}$ for total $\mathrm{HNO}_{3}$ and $\mathrm{NO}_{3}^{-}$. Our measurements for the aforementioned species, except $\mathrm{SO}_{2}$, were comparable with those measured in the above study. We suggested that our site experienced a higher level of sulfates during the sampling period,. Meanwhile, primary sources such as $\mathrm{SO}_{2}$ were in a limited amount. In addition, most of the $\mathrm{SO}_{2}$ may have converted to $\mathrm{SO}_{4}{ }^{2-}$ before it anived at the site. Notably, there were no major sources of $\mathrm{SO}_{2}$ in the vicinity of the site, even from the nearest urban areas. The $\mathrm{SO}_{4}{ }^{2-}$ originated from somewhere else.

\section{DEPOSITION OF SULFUR AND NITROGEN COMPOUNDS ON THE FU-SHAN FOREST}

\subsection{Estimation of Deposition Fluxes of $\mathrm{S}$ and $\mathrm{N}$ Compounds}

The deposition flux $\left(F_{i}\right)$ for a species $(i)$ can be calculated by the following equation,

$$
F_{i}=I \cdot C_{i},
$$

where $I$ is the dry deposition velocity (in $\mathrm{cm} \mathrm{s}^{-1}$ ) and precipitation intensity (in $\mathrm{mm} \mathrm{hr}^{1}$ ), and $C_{i}$ is the concentration of species $i$ in the air and precipitation, respectively, for dry and wet deposition.

In this study, dry deposition velocities were calculated using the ATDD (Atmospheric Turbulence and Diffusion Division, National Oceanic and Atmospheric Administration, see Hicks et al., 1987). Primary input meteorological parameters of ATDD are the wind speed 
(U), wind direction deviation $\left(\sigma_{\theta}\right)$, temperature (T), relative humidity (RH), and solar radiation (PAR). Table 4 lists the seasonal averages of above parameters. In addition, the leaf area index (LAI) is assumed to be 8.93, based on earlier measurements (King and Hsia, 1997). Detailed discussion can be found in Hicks et al. (1987) and Lin (1997).

Table 4: Meteorological parameters as inputs for ATDD model, measured at the Fu-Shan site during the summer (June - August) and winter (December - February) of 1993.

\begin{tabular}{cccccc}
\hline Season & $\mathrm{U}\left(\mathrm{m} \mathrm{s}^{-1}\right)$ & $\sigma_{\theta}$ (deg.) & $\Upsilon\left({ }^{\circ} \mathrm{C}\right)$ & $\mathrm{RH}(\%)$ & $\mathrm{PAR}\left(\mathrm{W} \mathrm{m}^{-2}\right)$ \\
\hline Summer & $1.44 \pm 0.83^{*}$ & $16.0 \pm 12.7$ & $24.7 \pm 3.4$ & $99.2 \pm 2.3$ & $206.7 \pm 294.3$ \\
Winter & $1.57 \pm 1.17$ & $16.4 \pm 12.5$ & $14.9 \pm 5.0$ & $99.2 \pm 5.4$ & $138.1 \pm 187.3$ \\
\hline
\end{tabular}

* mean \pm standard deviation

\subsection{Dry Deposition}

Based on ATDD model, Table 5 summarizes the average dry deposition velocities $\left(V_{d}\right)$ of $\mathrm{HNO}_{3}, \mathrm{SO}_{2}, \mathrm{NH}_{4}^{+}, \mathrm{SO}_{4}{ }^{2-}$ and $\mathrm{NO}_{3}^{-}$, and their seasonal dry deposition fluxes $\left(F_{d}\right)$. The results are discussed below.

The $V_{d}$ of above pollutants in winter were commonly greater than those in summer, primarily resulting from higher wind speeds during the former season. For gaseous $\mathrm{HNO}_{3}$ and $\mathrm{SO}_{2}$, their average $V_{d}$ ranged $0.79-0.90$ and $0.19-0.20 \mathrm{~cm} \mathrm{~s}^{-1}$, respectively. Walcek et al. (1986) obtained 2.5 and $0.8 \mathrm{~cm} \mathrm{~s}^{-1}$ for daytime $\mathrm{HNO}_{3}$ and $\mathrm{SO}_{2}$, respectively, at an altitude of $40 \mathrm{~m}$ above ground for eastern USA and southeastern Canada, based on model calculations. They also found that the $V_{d}$ was strongly dependent on meteorological conditions. Regarding particulate nitrogen compounds, our average $V_{d}$ of $\mathrm{NH}_{4}{ }^{+}$and $\mathrm{NO}_{3}{ }^{-}$ranged between 0.11-0.13 and $0.15-0.18 \mathrm{~cm} \mathrm{~s}^{-1}$, respectively. Our average $V_{\text {a }}$ fell into the lower bounds of the above studies. Table 6 further compares our $V_{d}$ of $\mathrm{SO}_{4}{ }^{2}$ and $\mathrm{NO}_{3}{ }^{-}$with other studies in Taiwan. In summary, for southern Taiwan the $V_{d}$ of $\mathrm{SO}_{4}{ }^{2-}$ and $\mathrm{NO}_{3}^{-}$ranged in $0.27-0.81$ and $0.10-0.45 \mathrm{~cm} \mathrm{~s}^{-1}$, respectively. Our $V_{d}$ of $\mathrm{SO}_{4}{ }^{2}$ was generally no more than half of that measured in other studies. The $V_{d}$ of $\mathrm{SO}_{4}{ }^{2-}$ and $\mathrm{NO}_{3}^{-}$in our study was less than half of those obtained in Kaohsiung (Chen et al., 1996) and Taichung (Jeng et al., 1996), but comparable with those observed in Tainan (Chen and Wu, 1994) and Pingtung (Chen et al., 1996). Based on above comparison, our $V_{d}$ of particulate pollutants were found to be generally lower than those of other studies, primarily attributed to low wind speeds at the Fu-Shan site. Meanwhile, our $V_{d}$ of and $\mathrm{SO}_{2}$ was comparable with other studies, whereas our $V_{d}$ of and $\mathrm{HNO}_{3}$ was evidently lower since the latter gas is more sensitive to the wind speed (Lin, 1997).

Using the average concentrations (see Tables 3 and 4) and $V_{d}$ of the above pollutants as representative values for the entire season, their seasonal $F_{d}$ were therefore extrapolated from average deposition fluxes over the 10-day sampling duration during both $\mathrm{P} 1$ and $\mathrm{P} 2$, as listed in Table 5. In addition, we calculated the seasonal $F_{d}$ for individual pollutants by summing the 
Table 5. Average deposition velocities $\left(V_{d}, \mathrm{~cm} \mathrm{~s}^{-1}\right)$ and seasonal deposition fluxes $\left(F_{d}, \mathrm{~kg} \mathrm{ha}^{-1}\right)$ of primary gaseous and particulate pollutants inferred by ATDD, based on the measurements at the Fu-Shan site during P1 and P2.

\begin{tabular}{|c|c|c|c|c|c|c|c|c|c|c|}
\hline \multirow[t]{2}{*}{ Season } & \multicolumn{2}{|c|}{$\mathrm{HNO}_{3}$} & \multicolumn{2}{|l|}{$\mathrm{SO}_{2}$} & \multicolumn{2}{|c|}{$\mathrm{NH}_{4}^{+}$} & \multicolumn{2}{|c|}{$\mathrm{SO}_{4}{ }^{3-}$} & \multicolumn{2}{|c|}{$\mathrm{NO}_{3}^{-}$} \\
\hline & $V_{d}$ & $F_{d}$ & $V_{d}$ & $F_{d}$ & $V_{d}$ & $F_{d}$ & $V_{d}$ & $F_{d}$ & $V_{d}$ & $F$ \\
\hline Summer & $0.79 \pm 0.75$ & 0.44 & $0.19 \pm 0.22$ & 0.09 & $0.11 \pm 0.22$ & 0.16 & $0.12 \pm 0.25$ & 0.73 & $0.15 \pm 0.31$ & 0.09 \\
\hline Winter & $0.90 \pm 0.80$ & 0.07 & $0.20 \pm 0.24$ & 0.26 & $0.13 \pm 0.21$ & 0.08 & $0.14 \pm 0.24$ & 0.37 & $0.18 \pm 0.29$ & 0.13 \\
\hline
\end{tabular}

Table 6. Comparison of our concentration $\left(C, \mu \mathrm{g} \mathrm{m}^{-3}\right), V_{d}\left(\mathrm{~cm} \mathrm{~s}^{-1}\right)$ and seasonal $F_{d}\left(\mathrm{~kg} \mathrm{ha}^{-1}\right)$ of $\mathrm{SO}_{4}{ }^{2-}$ and $\mathrm{NO}_{3}^{-}$with other studies in Taiwan.

\begin{tabular}{|c|c|c|c|c|c|c|c|c|}
\hline \multirow{2}{*}{ Investigator } & \multirow{2}{*}{ Period } & \multirow{2}{*}{ Location } & \multicolumn{3}{|c|}{$\mathrm{SO}_{4}{ }^{2-}$} & \multicolumn{3}{|c|}{$\mathrm{NO}_{3}^{-}$} \\
\hline & & & $C$ & $V_{d}$ & $F_{d}$ & $C$ & $V_{d}$ & $F_{d}$ \\
\hline Chen et al. (1996) & $12 / 1995-5 / 1996$ & Kaohsiung & $3.55-29.03$ & 0.38 & $1.05-8.58$ & $1.03-7.24$ & 0.45 & $0.34-2.54$ \\
\hline Jeng et al. (1996) & $12 / 1995-1 / 1996$ & Taichung & $11.02 \pm 2.29$ & 0.27 & $1.35-2.32$ & $7.37 \pm 2.72$ & 0.41 & $1.48-3.22$ \\
\hline Chen and Wu (1994) & $12 / 1993-2 / 1994$ & Tainan & 5.8 & 0.81 & $1.49-4.24$ & 11 & 0.17 & $0.57-1.90$ \\
\hline Chen et al. (1996) & $12 / 1995$ & Pingtung & 35.17 & 0.29 & 7.93 & 17.8 & 0.10 & 1.38 \\
\hline \multirow[t]{2}{*}{ This study } & Summer 1993 & Fu-Shan & $7.37 \pm 1.55$ & 0.12 & 0.73 & $0.72 \pm 0.15$ & 0.15 & 0.09 \\
\hline & Winter 1993 & Fu-Shan & $3.34 \pm 0.83$ & 0.14 & 0.37 & $0.93 \pm 0.28$ & 0.18 & 0.13 \\
\hline
\end{tabular}


product of their average concentrations and corresponding hourly $V_{d}$ over the entire season. By comparing both methods for $F_{d}$, except for $\mathrm{SO}_{2}$ that the former $F_{d}$ was $40-60 \%$ higher than the latter, the relative errors between both $F_{d}$ were generally within 20\%. This significant difference between both $F_{d}$ for $\mathrm{SO}_{2}$ was attributed to a larger fluctuation of its $V_{d}$.

Consequently, $F_{d}$ of total $\mathrm{NO}_{3}{ }^{-}$in summer $\left(0.53 \mathrm{~kg} \mathrm{ha}^{-1}\right)$ was more than twice that in winter $\left(0.20 \mathrm{~kg} \mathrm{ha}^{-1}\right)$. In the former season, $\mathrm{HNO}_{3}$ accounted for most of total deposition, whereas $\mathrm{NO}_{3}^{-}$contributed about half in the latter season. The above results support the previous point that active photochemsitry in summer made more products of $\mathrm{NO}_{3}{ }^{-}$at our site. Similarly, $F_{d}$ of $\mathrm{SO}_{4}^{2-}$ in summer $\left(0.73 \mathrm{~kg} \mathrm{ha}^{-1}\right)$ was approximately twice that in winter $(0.37 \mathrm{~kg} \mathrm{ha}-$ 1); yet, the $F_{d}$ of total $\mathrm{SO}_{2}$ for the former $\left(0.09 \mathrm{~kg} \mathrm{ha}^{-1}\right)$ was only $35 \%$ of that for the latter $(0.26$ $\mathrm{kg} \mathrm{ha}^{-1}$ ), as attributed to higher $\mathrm{SO}_{2}$ observed in winter. Table 6 shows that $F_{d}$ of $\mathrm{SO}_{4}{ }^{2-}$ and $\mathrm{NO}_{3}^{-}$from Taichung to Pingtong varied in 0.29-8.10 and 0.34-3.22 $\mathrm{kg} \mathrm{ha}^{-1}$, respectively. As to $\mathrm{NH}_{4}^{+}$dry deposition, it was associated with $\mathrm{SO}_{4}{ }^{2-}$ and $\mathrm{NO}_{3}{ }^{-}$, as discussed previously. Comparison with other studies indicated that the Fu-Shan forest received substantially low $\mathrm{S}$ and $\mathrm{N}$ inputs through dry deposition pathway, either due to lower ambient concentration levels of pollutants and/or relatively stable meteorological conditions (to decrease the dry deposition velocities).

\subsection{Wet Deposition}

Regarding wet deposition $\left(F_{w}\right)$, the deposition fluxes of $\mathrm{S}$ and $\mathrm{N}$ compounds for each event were directly computed as the product of precipitation intensity and their concentrations in rainwater. Furthermore, seasonal deposition fluxes were accumulated as the sum of individual contribution from each event during the field season. Consequently, Table 7 shows the average $\mathrm{NH}_{4}^{+}, \mathrm{SO}_{4}^{2-}$ and $\mathrm{NO}_{3}{ }^{-}$concentrations in rainwater collected at the Fu-Shan site, as well as their seasonal $F_{w}$ during the summer and winter field seasons of 1993 . The average $\mathrm{pH}$ of rainwater in winter was 0.58 units lower than that in summer, indicating that the acidity of the former was approximately 3.8 times higher than that of the latter. This result was apparently attributed to much higher $\mathrm{SO}_{4}^{2-}$ and $\mathrm{NO}_{3}{ }^{-}$in rainwater in winter, which were more than twice the continental baseline concentrations measured for Colorado (Hidy, 1994). By contrast, our $\mathrm{SO}_{4}{ }^{2-}$ and $\mathrm{NO}_{3}{ }_{3}^{-}$in summer was comparable with national average of Japan (Hara et al., 1995). Seasonal baseline $F_{w}$ of both $\mathrm{SO}_{4}^{2-}$ and $\mathrm{NO}_{3}{ }^{-}$for Colorado (Hidy, 1994) were generally as low as $1.5 \mathrm{~kg} \mathrm{ha}^{-1}$, as attributed to low annual rainfall of around $40 \mathrm{~mm}$ only. Seasonal average $F_{w}$ of above two ions in Japan (Hara et al., 1995) were approximately 7.5 and $3.0 \mathrm{~kg} \mathrm{ha}^{-1}$, respectively. The maximum seasonal $F_{w}$ of $\mathrm{SO}_{4}{ }^{2-}$ and $\mathrm{NO}_{3}{ }^{-}$in the eastern USA during 1985-1987 (NAPAP, 1991) were around 11 and $7 \mathrm{~kg} \mathrm{ha}^{-1}$, respectively. Our $F_{w}$ of these two ions in summer was comparable with those of the above other studies, but substantially higher in winter. Chen et al. (1996) and Lin et al. (1999) have pointed out that relatively high $\mathrm{SO}_{4}{ }^{2-}$ in rainwater and its wintertime $F_{w}$ at our site which were primarily associated with northeast monsoon flows, to a greater extent resulted from the long-range transport.

\subsection{Budget of $S$ and $N$ Deposition}

In order to investigate the relative importance of atmospheric inputs via various deposi- 
tion pathways onto the $\mathrm{Fu}$-Shan forest, total $\mathrm{S}$ and $\mathrm{N}$ depositions were calculated as the sum of all $\mathrm{S}\left(\mathrm{SO}_{2}\right.$ and $\left.\mathrm{SO}_{4}^{2-}\right)$ and $\mathrm{N}\left(\mathrm{HNO}_{3}, \mathrm{NO}_{3}{ }^{-}\right.$and $\left.\mathrm{NH}_{4}{ }^{+}\right)$compounds by dry and wet depositions, respectively. Table 8 lists the results of deposition budgets of $\mathrm{S}$ and $\mathrm{N}$ compounds for the summer and winter field seasons. The $F_{d}$ of $\mathrm{N}$ compounds in summer was more than twice that in winter, and vice versa for $F_{w}$. For total S deposition, the $F_{d}$ pathway contributed only 6.5 and $1.5 \%$ in summer and winter, respectively. With regard to $S$ compounds, $F_{d}$ in summer and winter were at the same level, whereas $F_{w}$ in summer was less than half of that in winter. For total S deposition, the $F_{d}$ pathway contributed only 5.1 and $2.0 \%$ in summer and winter, respectively. Evidently, $F_{w}$ was the dominant pathway for delivering both $\mathrm{S}$ and $\mathrm{N}$ compounds from the atmosphere to the Fu-Shan forest in summer and winter. By contrast, in a hardwood forest in Tennessee, USA, $F_{d}$ can account for 56 and $63 \%$ of $\mathrm{SO}_{4}{ }^{2-}$ and $\mathrm{NO}_{3}{ }^{-}$deposition, respectively (Lindberg et al., 1986). In addition, the fraction of $\mathrm{SO}_{4}{ }^{2-}$ and $\mathrm{NO}_{3}$ through dry deposition ranged between 0.2-0.5 and 0.30-0.45, respectively at the CORE sites (Sisterson et al., 1990). Lindberg and Lovett (1992) reported that the $F_{d}$ pathway contributed $15-48 \%$ of $\mathrm{SO}_{4}{ }^{2-}$ in 11 forested sites in USA. According to NAPAP (1991) in the eastern USA 30-60 and 30-70\% of total $\mathrm{S}$ and $\mathrm{N}$ depositions resulted from $F_{d}$, respectively.

Comparison of other studies (Lindberg et al., 1986; Sisterson et al., 1990; NAPAP, 1991; Lindberg and Lovett, 1992) with the present study indicated that at our site wet deposition became an extremely important pathway to remove gaseous and particulate pollutants from the atmosphere to forest canopies and collecting surfaces, primarily resulting from higher rainfall received by the Fu-Shan forest. In addition, relatively high $\mathrm{SO}_{4}{ }^{2 \cdot}$ and $\mathrm{NO}_{3}^{-}$loading in raindrops can be merely attributed to below-clouds scavenging to a lesser extent since ambient concentration levels of these pollutants were significantly low. Therefore, we believe that atmospheric wet inputs to the Fu-Shan forest should largely derive from the long-range transport rather than local emissions, particularly in winter.

\section{CONCLUDING REMARKS}

In this study chemical constituents of atmospheric pollutants in solid, gaseous and liquid phases, in particular, for $\mathrm{S}$ and $\mathrm{N}$ compounds, at the Fu-Shan forest during the field experiments (around two weeks for each experiment) in summer and winter of 1993, were investigated. The budget of $\mathrm{S}$ and $\mathrm{N}$ inputs to the Fu-Shan forest through dry and wet deposition pathways was assessed as well. Our major findings are highlighted below:

- The bimodality in AP mass spectra was found. For the observations in summer, the fine (a cut size $<1.0 \mu \mathrm{m}$ ) and coarse (a cut size $\sim 3.2 \mu \mathrm{m}$ ) modes were primarily composed of ammonium sulfate and nitrate, respectively. But, for the observations in winter, sea salts became dominant composition in coarse mode due to the influences of the northeast monsoon flows.

- By mass, $\mathrm{SO}_{4}{ }^{2-}$ was the principal water soluble composition $(66.1 \pm 0.8 \%$ and $38.2 \pm 10 \%$ for the observations in summer and winter, respectively) in $\mathrm{AP}$, followed by $\mathrm{NH}_{4}^{+}$and $\mathrm{NO}_{3}^{-}$. In terms of the ion equivalent concentration, $\mathrm{SO}_{4}{ }^{2-}$ and $\mathrm{NH}_{4}{ }^{+}$were the principal components 
Table 7. Precipitation chemistry and estimated seasonal wet deposition $\left(F_{w}\right)$ of $\mathrm{NO}_{3}{ }^{-}, \mathrm{SO}_{4}{ }^{2-}$ and $\mathrm{NH}_{4}{ }^{+}$at the FuShan site during the summer and winter field seasons of 1993.

\begin{tabular}{|c|c|c|c|c|c|c|c|c|c|c|}
\hline \multirow[t]{2}{*}{ Season } & \multirow{2}{*}{\multicolumn{2}{|c|}{$\mathrm{N}$}} & \multirow[b]{2}{*}{$\mathrm{pH}$} & \multicolumn{3}{|c|}{ Concentration $\left(\mu \mathrm{eq} l^{\prime}\right)$} & \multirow[t]{2}{*}{ Rainfall (mm) } & \multicolumn{3}{|c|}{$F_{11}\left(\mathrm{~kg} \mathrm{ha}^{-1}\right)$} \\
\hline & & & & $\mathrm{NO}_{3}{ }^{-}$ & $\mathrm{SO}_{4}{ }^{2-}$ & $\mathrm{NH}_{4}{ }^{+}$ & & $\mathrm{NO}_{3}^{-}$ & $\mathrm{SO}_{4}{ }^{2-}$ & $\mathrm{NH}_{4}{ }^{+}$ \\
\hline Summer & 12 & $\mu \pm \sigma$ & $4.93 \pm 0.54$ & $17.15 \pm 13.3$ & $49.08 \pm 23.00$ & $17.59 \pm 14.77$ & 731.5 & 7.79 & 16.23 & 2.17 \\
\hline Winter & 10 & & $4.35 \pm 0.26$ & $65.55 \pm 54.4$ & $123.63 \pm 67.11$ & $41.61 \pm 29.33$ & 633.0 & 17.00 & 36.56 & 4.51 \\
\hline
\end{tabular}

Table 8. Deposition budget of $\mathrm{S}$ and $\mathrm{N}$ compounds on the Fu-Shan forest during the summer and winter field seasons of 1993 (Unit: $\mathrm{kg} \mathrm{ha}^{-1}$ ).

\begin{tabular}{|c|c|c|c|c|c|c|c|c|}
\hline \multirow[t]{2}{*}{ Season } & \multicolumn{2}{|c|}{$F_{d}$} & \multicolumn{2}{|c|}{$F_{w}$} & \multicolumn{2}{|c|}{$F_{r}\left(F_{s}+F_{\mathrm{w}}\right)$} & \multicolumn{2}{|c|}{$F_{d} / F_{T} \quad(\%)$} \\
\hline & $\mathrm{N}$ & $S$ & $\mathrm{~N}$ & $S$ & $\mathrm{~N}$ & $\mathrm{~S}$ & $\mathrm{~N}$ & $S$ \\
\hline Summer & 0.24 & 0.29 & 3.45 & 5.41 & 3.69 & 5.70 & 6.5 & 5.1 \\
\hline Winter & 0.11 & 0.25 & 7.35 & 12.19 & 7.46 & 12.44 & 1.5 & 2.0 \\
\hline
\end{tabular}


for the observations in summer. However, instead of $\mathrm{NH}_{4}^{+}, \mathrm{Na}^{+}$and $\mathrm{Cl}^{-}$became the secondary ions for the observations in winter.

- Our average $\mathrm{HNO}_{2}(\sim 0.10 \mathrm{ppb})$ was appreciably higher than those observed in clean troposphere, whereas $\mathrm{HNO}_{3}$ was at a comparable level. Mean concentration of total nitrates $\left(\mathrm{HNO}_{3}+\mathrm{NO}_{3}^{-}\right)$was higher than background value in troposphere. Ammonia gas and particulate ammonium were at a lower concentration level, compared with those generally observed on the continental grounds. The $\mathrm{SO}_{2}(<1 \mathrm{ppb})$ was comparable with those frequently observed in the free troposphere, while $\mathrm{SO}_{4}{ }^{2-}$ was close to the lowest level typically obtained in urban areas. We believe that $\mathrm{SO}_{4}^{2-}$, to a larger extent, was ransported to the site via the long-range transport, particularly in winter. Meanwhile, ammonium production became less in winter due to lower temperatures.

- Dry $\mathrm{S}$ and $\mathrm{N}$ depositions in summer were appreciably higher than in winter. In contrast, wet $\mathrm{S}$ and $\mathrm{N}$ depositions in winter were more than twice those in summer, primarily attributed to high $\mathrm{SO}_{4}^{2-}$ and $\mathrm{NO}_{3}^{-}$loading in raindrops in wintertime precipitation. For total $\mathrm{S}$ deposition, dry deposition pathway contributed only 5.1 and $2.0 \%$ in summer and winter, respectively. For total $\mathrm{N}$ deposition, dry deposition pathway accounted for 6.5 and $1.5 \%$ in summer and winter, respectively. Uncertainties in estimating dry deposition can be on an order of 10 in magnitude owing to several factors primarily including the topographic complexity, and profiles of boundary layer parameters above and within forest canopy. Nevertheless, wet deposition pathway was evidently the most effective deposition mechanism to deliver atmospheric $\mathrm{S}$ and $\mathrm{N}$ compounds to the Fu-Shan forest during the field seasons.

Our investigations have resulted, for the first time, in quantitative assessment of atmospheric chemical inputs to a rural mountain forest in the subtropical Taiwan. Although the data coverage is only for two field experiments, the results may elucidate, to some extent, a typical chemical condition encompassed at our site in summer and winter. In conclusion, our study provides very useful information for future investigations on $\mathrm{S}$ and $\mathrm{N}$ nutrient cycles in the biosphere-atmosphere system, as well as on the carrying capacity of the soil for the above two compounds.

Acknowledgments This study was supported by the National Science Council (NSC) under the contracts No. NSC-83-2020-M-008-03, NSC-84-2621-B-008-001-A07, NSC-85-2621-B008-001-A07 and NSC-86-2621-B-008-001-A07. Mr. T.-T. Lin of the Fu-Shan Research Station of the TFRI gave a great deal of help in assisting the experimental setup and logistic supports. Dr. P. F. Lee of National Taiwan University provided Fig. 1. Ms. C.-B. Liu of the TFRI analyzed the rain water samples. Mr. K.-S. Wang did chemical analysis for the samples of annular denuder. Mr. C.-M. Peng and Ms. M.-R. Lin prepared the tables and figures. Thanks are also given to those graduate and undergraduate students who helped performing the field experiments. Comments and suggestions from three anonymous reviewers are highly appreciated.

\section{REFERENCES}

Altshuller, A. P., 1976: Regional transformation of sulfur dioxide to sulfate in the U. S. J. Air 
Pollut. Control Assoc., 26, 318-324.

Altshuller, A. P., 1980: Seasonal and episodic trends in sulfate concentrations in the eastern United States. Environ. Sci. Technol., 14, 1337-1349.

Chen, C.-S., N.-H. Lin, C.-M. Peng, and F.-T. Jeng, 1996: Acidic deposition on Taiwan and associated precipitation systems. In Proceedings of International Conference on Acid Deposition in East Asia, Taipei, Taiwan, May 28-30, 1996.

Chen, J. Y. and Y. L. Wu, 1994: Size distribution and dry deposition velocity of particulates. In Proceedings of 11th Air Pollution Control Technology, Taichung, 232-238.

Chen, S. J., C. C. Lin, C. C. Chang, C. H. Shu, and S. J. Chen, 1996: Size distribution and dry deposition velocity of atmospheric sulfate and nitrate. In Proceedings of 13th Air Pollution Control Technology, Taipei, 1119-1126.

Chen, S. J., G. C. Fang, C. C. Lin, C. C. Chang, C. H. Shu, and F. J. Chen, 1996: Measure and modeling the anion species in Ping Tung, Taiwan. In Proceedings of International Conference on Acid Deposition in East Asia. Taipei, Taiwan, May 28-30, 1996, 269-279.

Dasch, J. M., and S. H. Cadle, 1985: Wet and dry deposition monitoring in southwestern Michigan. Atmos. Environ., 19, 789-796.

Georgii, H. W., and U. Lenhard, 1978: Contribution to atmospheric $\mathrm{NH}_{3}$ budget. Pure Appl. Geophys., 116, 385-391.

Hanst, P. L., N. M. Wong, and J. Bragin, 1982: A long path infra-red study of Los Angeles smog. Atmos. Environ., 16, 969-981.

Hara, H., M. Kitamura, A. Mori, I. Noguchi, T. Ohizumi, S. Seto, T. Tadashi, and T. Deguchi, 1995: Precipitation chemistry in Japan 1989-1993. Water, Air and Soil Pollut., 85, 2307-2312.

Hicks, B. B., D. D. Baldocchi, T. P. Meyers, R. P. Hosker, and D. R. Matt, 1987: A preliminary multiple resistance routine for deriving dry deposition velocities from measured quantities. Water, Air and Soil Pollut., 36, 311-330.

Hidy, G. M., 1994: Atmospheric Sulfur and Nitrogen Oxides: Eastern North American SourceReceptor Relationships. Academic Press, San Diego.

Huebert, B. J., and A. L. Lazrus, 1980: Tropospheric gas-phase and particulate nitrate measurements. J. Geophys. Res., 85, 7322-7328.

Huebert, B. J., and C. H. Robert, 1985: The dry deposition of nitric acid to grass. J. Geophys. Res., 90, 2085-2090.

Jeng, M. T., K. H. Jeng, K. C. Feng, and B. J. Chung, 1996: Daytime and nighttime characteristics of dry deposition of atmospheric aerosol and its water soluble ions. In Proceedings of 13th Air Pollution Control Technology, Taipei, November 23-24, 1996, 11551162.

King, H.-B., and Y.-J. Hsia, 1997: Establish, progress and performance of the Taiwan Ecological Research Network (TERN) program. In Proceedings of the First East-Pacific Regional Conference on Long-Term Ecological Research (Edited by King, H.-B., S. P. Hamburg and Y.-J. Hsia). I-Lan, Taiwan, April 7-13, 1995.

Lin, N.-H., M.-B. Chang, and H.-M. Lee, 1999: Evaluation of the characteristics of acid precipitation in Taipei, Taiwan using cluster analysis. Water, Air and Soil Pollut., 113, 241-260. 
Lin, N.-H. and V. K. Saxena, 1991: Interannual variability in acidic deposition on the Mt. Mitchell area forest. Atmos. Environ., 25A, 517-524.

Lin, W.-L., 1997: Estimation of Acidic Deposition on the Fu-Shan Forest. M.S. Thesis, National Central University, Chung-Li.

Lindberg, S. E., and G. M. Lovett, 1992: Deposition and forest canopy interactions of airbome sulfur: results from the integrated forest study. Atmos. Environ., 26A, 1447-1492.

Lindberg, S. E., G. M. Lovett, D. D. Richter and D. W. Johnson, 1986: Atmospheric deposition and canopy interactions of major ions in a forest. Science, 231, 141-145.

Marple, V. A., K. L.Rubow, and S. M. Behm, 1991: A microorifice uniform deposit impactor (MOUDI): description, calibration, and use. Aerosol Sci. and Technol., 14, 434-446.

McNulty, S., J. Alber, and R. Boone, 1991: Spatial changes in forest floor and foliar chemistry of spruce-fir forests across New England. Biogeochemistry, 14, 13-29.

Mueller, S. F., and F. P. Weatherford, 1988: Chemical deposition to a high elevation red spruce forest. Water, Air and Soil Pollut., 38, 345-363.

NAPAP, 1991: 1990 Integrated Assessment Report, National Acid Precipitation Assessment Program. The NAPAP Office, Washington, DC.

Ohta, S., and T. Okita, 1990: A chemical characterization of atmospheric aerosol in Sapporo. Atmos. Environ., 24A, 815-822.

Ollinger, S, J. Alber, G. Lovett, S. Millham, R. Lathrop, and J. Ellis, 1993: A spatial model of atmospheric deposition for the Northeastern U.S. Ecol. Appl., 3, 459-472.

Perrino, C., F. D. Santis, and A. Febo, 1990: Criteria for the choice of a denuder sampling technique devoted to the measurement of atmospheric nitrous and nitric acids. Atmos. Environ., 24A, 617-626.

Ryaboshapko, A. G., 1983: The atmospheric sulfur cycle. In: Ivanov, M. V. and J. R. Freney (Eds.). The Global Biogeochemical Sulfur Cycle, SCOPE., 19, 203-296.

Seinfeld, J. H., 1986: Atmospheric Chemistry and Physics of Air Pollution. John Wiley \& Sons, Inc., New York.

Sisterson, D. L., 1990: Deposition monitoring: methods and results, NAPAP State of Science and Technology Report 6. National Acid Precipitation Assessment Program, Washington, DC.

Sopauskiene, D., and D. Budvytyte, 1994: Chemical characteristics of atmospheric aerosol in rural site of Lithuania. Atmos. Environ., 28, 1291-1296.

Tanner, R. L., 1990: Sources of acids, bases, and their precursors in the atmosphere. In: Lindberg, A. L., A. L. Page and S. A. Norton (Eds.), Acidic Precipitation. Vol. III: Sources, Deposition and Canopy Interactions, Springer-Verlag, New York, 1-19.

Tanner, R. L., 1980: Sulfur and nitrogen compounds in urban aerosols. Ann. NY. Aca. Sci., 338, 39-49.

Vitousek, P. M., and P. Matson, 1988: Nitrogen transformations in a range of tropical forest soils. Siol Biology Biochem., 20, 361-367.

Walcek, C. J., R. A. Brost, and J. C. Chang, 1986: $\mathrm{SO}_{2}$, sulfate and $\mathrm{HNO}_{3}$ deposition velocities computed using regional landuse and meteorological data. Atmos. Environ., 20, 949-964. 
Warneck, P., 1988: Chemistry of the Natural Atmosphere. Harcourt Brace Jovanovich, Publisher. 